Kodifikasia : Jurnal Penelitian Islam, Vol 14, No. 01 (2020), 147-170

DOI : 10.21154/kodifikasia.v14i1.1993

ISSN : 1907-6371 (Cetak)

ISSN : 2527-9254 (Online)

\title{
POLITIK HUKUM DISKRESI DI INDONESIA: ANALISIS TERHADAP PEMBAGIAN KEKUASAAN ANTARA PEMERINTAH DAN LEGISLATIF
}

\author{
Endrik Safudin*
}

\begin{abstract}
ABSTRAK:
Diskresi (freies ermessen) merupakan kebebasan bertindak atas inisiatif sendiri yang dimiliki oleh Pemerintah atau pejabat administrasi negara. Diskresi sebagai sarana untuk mengatasi persoalan-persoalan yang penting, mendesak, muncul secara tiba-tiba, yang pengaturannya memberikan pilihan atau belum ada atau kewenangannya yang tidak jelas atau samar-samar. Pemerintah atau pejabat administrasi negara dalam menggunakan kekuasaan diskresi harus dapat mempertanggungjawabkannya baik secara hukum maupun moral. Penggunaan diskresi hanya ditujukan demi kepentingan umum. Oleh karena itu, diskresi hadir sebagai alternatif untuk memenuhi kekurangan dan kelemahan implementasi asas legalitas (wetmatigheid van bestuur). Ia sebagai pelengkap terhadap asas legalitas, namun bukan mengesampingkan hukumnya sama sekali. Dengan menggunakan deskriptifanalisis, penelitian ini fokus pada kajian politik hukum diskresi sebagai bentuk pembagian kekuasaan antara pemerintah dan legislatif. Pendekatan politik hukum memudahkan untuk menggali ulang konsep diskresi yang telah ada. Sehingga kajian ini tidak bisa dilepaskan dari penelusuran sejarah tentang konsep diskresi dimasa lalu telah dibuat dan seharusnya dibuat. Hasil penelitian ini menunjukkan tujuan "mulianya" dilahirkannya konsep diskresi dalam politik hukum di indonesia. Sehingga, penggunaannya harus benar-benar untuk mendukung kesejahteraan dan kepentingan umum.
\end{abstract}

Kata kunci: Diskresi; Inisiatif; Politik Hukum; Asas legalitas

*Institut Agama Islam Negeri Ponorogo, email: safudinendrik@gmail.com 


\begin{abstract}
:
Discretion (freies ermessen) is a freedom of action on self-initiative which is owned by the Government or state administration officials. Discretion is a tool to overcome the important, urgent and emergent problems, and the arrangement provide choices or the authority is unclear or vague. The government or state administration officials in using discretionary power must be able to take responsibility both legally and morally. The use of discretion is only intended for the public interest. Therefore, discretion exists as an alternative to meet the weaknesses in the implementation of the legality principle (wetmatigheid van bestuur). It was as a complement to the principle of legality, but does not ignore the law itself at all. By using descriptiveanalysis, this research focuses on the study of discretionary political law as a form of power sharing between the government and legislative. The political of law approach make it easy to re-explore the existing concept of discretion. So this study cannot be separated with the historical traces about the concept of discretion in the past that have been made. The results of this study indicate the purpose of the "nobility" of the discretion concept in the legal politics in Indonesia. So, its implementation must really support the welfare and the public interest.
\end{abstract}

Keywords: Discretion; Initiative; Legal politics; The principle of legality

\title{
PENDAHULUAN
}

Perpindahan konsep negara ikut aktif dalam pergaulan kemasyarakatan memaksa negara untuk wajib dalam menyelenggarakan kesejahteraan umum (bestuurszorg). ${ }^{1}$ Tugas bestuurszorg membawa konsekuensi khusus bagi administrasi Negara yaitu untuk dapat bertindak atas inisiatif sendiri. Tindakan ini hadir ketika dihadapkan pada penyelesaian persoalan genting sedangkan peraturan yang mengaturnya belum ada atau belum dibuat oleh lembaga legislatif. ${ }^{2}$ Tindakan itu dikenal dengan istilah freies ermessen.

Di era modern ini, diskresi (freies ermessen) sangat penting untuk mempercepat tujuan kesejahteraan umum. Diskresi menjadi sarana ketika ada kekosongan atau kevakuman atas ketiadaan suatu aturan dalam mekanisme tertentu ketika suatu peristiwa konkrit yang mendesak untuk

${ }^{1}$ E. Utrecht, Pengantar Hukum Administrasi Negara Indonesia (Surabaya: Pustaka Tinta Mas, 1988), 28-29.

2 Ibid, 30-31.

Kodifikasia: Jurnal Penelitian Islam, Volume, 14 No. 1 Tahun 2020 
segera diambil suatu keputusan. Selain itu, diskresi menjadi terobosan untuk mendobrak stagnasi, mencari jalan pintas agar suatu program berjalan, atau menyiasati sesuatu agar tujuan yang diinginkan cepat tercapai. Namun perlu diketahui bahwa penggunaan diskresi dapat melahirkan peluang penyalahgunaan kekuasaan (abuse of power), pelampauan kewenangan (detournement de pouvoir, ultravires) dan keputusan sewenang-sewenang (willekeur) yang dilakukan oleh pejabat administrasi negara. Karena inilah hukum mengatur penggunaannya agar tidak otoriter. Hukum hadir untuk mengatur tindakan yang boleh dan tindakan yang dilarang bagi administrasi negara. Sehingga, segala perbuatan dan kewenangannya dibatasi oleh hukum.

Permasalahan yang menjadi perhatian adalah diskresi merupakan kebijakan yang dikeluarkan oleh pejabat administrasi negara (eksekutif). Sedangkan sistem ketatanegaraan mengatur bahwa tugas utama dari lembaga eksekutif adalah melaksanakan undang-undang bukan membuat undang-undang (legislasi). Landasan pemikiran ini berangkat dari konsep trias politica-nya Baron de Montesquieu yang membagi kekuasaan pemerintahan dalam tiga cabang, yaitu legislatif, eksekutif dan yudikatif. Ketiga cabang kekuasaan tersebut harus terpisah satu sama lain, baik mengenai tugas (fungsi) maupun mengenai alat perlengkapan (lembaga) yang menyelenggarakannya. ${ }^{3}$

Dalam perkembangannya, munculnya konsep negara kesejahteraan (welfare state) menjadikan pemerintah (eksekutif) bertanggungjawab atas kesejahteraan seluruh rakyat. Konsep ini memaksa fungsi kenegaraan jauh melebihi tiga macam fungsi yang disebut Montesquieu. Dampaknya, tidak lagi diterimanya asas bahwa eksekutif hanya bertindak sebagai pelaksana dari undang-undang, tetapi harus berpartisipasi secara aktif di bidang legislatif sendiri (seperti menyusun rancangan undang-undang, membuat penetapan presiden, peraturan menteri dan sebagainya) dan dalam bidang yudikatif (misalnya di Indonesia dalam sengketa perumahan, dalam konflik-konflik pajak). Begitu pula dalam menafsirkan undang-undang dan "membuat" undang-undang. ${ }^{4}$

${ }^{3}$ Bandingkan dengan Efi Yulistyowati, Endah Pujiastuti, dan Tri Mulyani, "Penerapan Konsep Trias Politica Dalam Sistem Pemerintahan Republik Indonesia: Studi Komparatif Atas Undang-Undang Dasar Tahun 1945 Sebelum Dan Sesudah Amandemen,"Jurnal Dinamika Sosial Budaya Volume 18, no. 2 (Desember 2016): 330. Lihat juga Kotan Y. Stefanus, Perkembangan Kekuasaan Pemerintahan Negara (Yogyakarta: Penerbit Universitas Atma Jaya, 1998), 29. Sofyan Hadi, "Fungsi Legislasi dalam Sistem Pemerintahan Presidensil (Studi Perbandingan Indonesia dan Amerika Serikat)," Jurnal Ilmu Hukum DIH vol 9, no. 18 (Februari 2013): 78.

${ }^{4}$ Bandingkan dengan Hans Kelsen, General Theory of Law and State (Cambridge, Massachusetts: Harvard University Press, 1949), 274-77. 
Dari sini telah nampak adanya pembagian kekuasaan antara pemerintah (eksekutif) dan legislator (legislatif). Pemerintah mempunyai kekuasaan untuk melakukan tindakan ketika peraturan perundangundangan tidak mengatur, tidak lengkap atau tidak jelas, dan/atau adanya stagnasi pemerintahan terutama ketika dihadapkan pada peristiwa konkret dan mendesak (diskresi). Diskresi (freies ermessen) tersebut adalah sarana responsif yang telah disediakan oleh lembaga legislatif.

Beberapa pertanyaan patut untuk menguji pembagian kekuasaan tersebut, mengapa diskresi menjadi kewenangan lembaga eksekutif. Apa alasan pemberian kewenangan diskresi kepada pemerintah. Bagaimana penggunaan diskresi yang dilakukan pemerintah sehingga tidak bertentangan dengan hukum dan bagaimana pemerintah menyediakan perangkat hukum diskresi yang lebih responsif dimasa mendatang.

Disinilah penelitian politik hukum diskresi dan pembagiannya dari kekuasaan pemerintah yang semula hanya melaksanakan peraturan perundang-undangan menjadi pembuat "peraturan perundang-undangan" mendapatkan posisi penting. Pengkajian politik hukum diskresi akan memberikan sebuah sumbangsih dalam merancang peraturan hukum yang lebih responsif di masa mendatang. Sedangkan pembagian kewenangan memberikan sumbangsih bahwa segala tindakan pemerintah tetap mendapatkan batasan oleh hukum.

Penelitian tentang diskresi bukanlah hal baru dalam dunia akademik. Misalnya, artikel yang ditulis Yuniar Kurniawaty berjudul "Penggunaan diskresi dalam pembentukan produk hukum (The Use Of Discretion in the formation of a legal product), ${ }^{5}$ artikel yang ditulis Githa Angela Sihotang, Pujiyono dan Nabitatus Sa'adah yang berjudul "Diskresi dan Tanggungjawab pejabat publik pada pelaksanaan tugas dalam situasi darurat", 6 artikel yang ditulis Mohammad Yuhdi yang berjudul "Peranan Diskresi Dalam Penyelenggaraan Pemerintaha", 7 dan artikel yang ditulis Arfan Faiz Muhlizi yang berjudul "Reformasi Diskresi Dalam Penataan Hukum Administrasi (Reformation of Descretion In The Arrangement Administrative Law). ${ }^{8}$

${ }^{5}$ Yuniar Kurniawaty, "Penggunaan Diskresi Dalam Pembentukan Produk Hukum (The Use of Discretion in The Formation of a Legal Product)," Jurnal Legislasi Indonesia Vol. 13, no. 01 (Maret 2016).

${ }^{6}$ Githa Angela Sihotang, Pujiyono, dan Nabitatus Sa'adah, "Diskresi dan Tanggungjawab pejabat publik pada pelaksanaan tugas dalam situasi darurat," Jurnal Law Reform 13, no. 1 (Tahun 2017).

${ }^{7}$ Mohammad Yuhdi, "PERANAN DISKRESI DALAM PENYELENGGARAAN PEMERINTAHAN," Jurnal Ilmiah.Fakultas Keguruan dan Ilmu Pendidikan Volume. 15, no. 1 (t.t.).

${ }^{8}$ Arfan Faiz Muhlizi, "Reformasi Diskresi Dalam Penataan Hukum Administrasi (Reformation of Descretion In The Arrangement Administrative Law)," Jurnal Rechts Vinding Volume 1, no. 1 (April 2012).

Kodifikasia: Jurnal Penelitian Islam, Volume, 14 No. 1 Tahun 2020 
Berdasarkan kajian terhadap berbagai riset yang telah dilakukan sebelumnya, maka dapat disimpulkan bahwa penelitian ini adalah penelitian yang belum pernah dilakukan oleh peneliti sebelumnya. Karena dalam penelitian ini membahas tentang tentang Politik Hukum Diskresi di Indonesia (analisis terhadap pembagian kekuasaan antara pemerintah dan legislatif).

Dengan menggunakan descriptive-analyses, penelitian ini membahas diskresi yang difokuskan pada kajian politik hukum diskresi sebagai bentuk pembagian kekuasaan antara pemerintah dan legislatif. Kajian politik hukum diskresi terikat dari kajian bagaimana proses hadirnya diskresi dalam peraturan perundang-undangan, penyalahgunaan maupun pelanggaran penggunaan diskresi disaat ini dan dimasa lalu. Dengan pengertian lain, kajian politik hukum menuntut untuk menggali ulang konsep diskresi yang telah ada sehingga kajian ini tidak bisa dilepaskan dari penelusuran sejarah. Pelacakan sejarah dapat membantu untuk menangkap bagaimana konsep diskresi dimasa lalu telah dibuat dan seharusnya dibuat.

Pada konteks ini, sejarah hukum akan membantu untuk mengetahui kaidah-kaidah serta institusi-institusi hukum yang ada. ${ }^{9}$ Sejarah hukum juga membantu penelaahan sejumlah peristiwa-peristiwa yuridis dari zaman lampau yang disusun secara kronologis. ${ }^{10}$ Karena setiap negara memiliki hukum yang eksistensinya tak dapat dilepaskan dari perkembangannya di masa lampau. Hukum yang tumbuh adalah proses sambung-menyambung atau hubungan yang tak terpisahkan dari proses yang mendorong lahirnya hukum itu. ${ }^{11}$ Latar belakang munculnya produk hukum dapat dipengaruhi baik konteks politik, ekonomi religi-ideologi dan kultur budaya yang mengiringinya. ${ }^{12}$

\section{PEMBAHASAN}

\section{Konsep Politik Hukum}

Politik hukum merupakan konsep tentang penciptaan hukum yang akan diberlakukan dan diarahkan untuk merealisasikan tujuan bersama. Menurut Bernard L. Tanya, ${ }^{13}$ politik hukum, lebih serupa suatu etika, menggugat

${ }^{9}$ Soerjono Soekanto, Pengantar Sejarah Hukum (Bandung: Alumni, 1986), 9. Lihat juga Endrik Safudin, "Politik Hukum HAM di Indonesia," Justitia Islamica 12, no. 1 (2015): 108-9. 417.

${ }^{10}$ L.j. Van Apeldroon, Pengantar Ilmu Hukum (Bandung: PT. Pradnya Paramita, 2001),

${ }^{11}$ Emeritus John Gillisen dan Emeritus Frits Gorle, Sejarah Hukum: Suatu Pengantar (Bandung: PT. Refika Aditama, 2005), 91.

${ }^{12}$ Safudin, "Politik Hukum HAM di Indonesia," 110.

${ }^{13}$ Bernard L. Tanya, Politik Hukum Agenda Kepentingan Bersama (Yogyakarta: Genta Publishing, 2011), 2-3. 


\section{Endrik Safudin}

agar tujuan yang dipilih bisa dibenarkan dan di uji oleh akal sehat, dan upaya untuk mencapainya harus bisa diuji melalui kriteria moral.

Menurut Moh. Mahfud MD, politik hukum sebagai "legal policy” yang akan diberlakukan baik dengan pembuatan hukum baru maupun dengan penggantian hukum lama, dalam rangka mencapai tujuan negara. Ia merupakan pilihan tentang hukum-hukum yang akan diberlakukan, yang akan dicabut atau diberlakukan dalam rangka untuk mencapai tujuan negara seperti yang tercantum di dalam pembukaan UUD $1945 .{ }^{14}$ Menurut Soedarto, politik hukum sebagai usaha untuk mewujudkan peraturanperaturan yang baik sesuai dengan keadaan dan situasi pada suatu waktu untuk mencapai apa yang dicita-citakan. ${ }^{15}$ Pada konteks ini, politik hukum harus bertumpu pada tujuan negara dan sistem hukum yang berlaku dinegara yang bersangkutan. Di Indonesia tujuan dan sistem itu terkandung di dalam pembukaan UUD 1945, khususnya Pancasila, yang melahirkan kaidah-kaidah penuntun hukum. ${ }^{16}$

Dengan demikian, dapat disimpulkan bahwa politik hukum mencakup proses pembuatan, pembaruan dan pelaksanaan hukum yang dapat menunjukkan sifat dan kearah mana hukum akan dibangun dan ditegakkan. Artinya, politik hukum mencakup proses hukum yang telah dibuat dan berlaku saat ini (ius constitutum) serta bagaimana seharusnya hukum dibuat dan berlaku dimasa yang akan datang (ius constituendum) untuk mencapai tujuan bersama. Sehingga, dapat diketahui apakah politik hukum yang akan dibangun dan ditegakkan telah sesuai atau telah keluar dari tujuan bersama tersebut. Oleh karena itu, inti dari politik hukum adalah persoalan pencapaian tujuan bersama. Ada tujuan ideal yang menjadi tanggungjawab hukum untuk diwujudkan. Aspek tujuan ideal itulah yang menjadi poros politik hukum. ${ }^{17}$

\section{Konsep Diskresi}

Diskresi adalah kebebasan bertindak atas inisiatif sendiri. Tindakan tersebut dilakukan atas dasar kekuasaan atau yang melekat pada pejabat

${ }^{14}$ Moh. Mahfud MD, Politik Hukum di Indonesia, Revisi, vol. Keempat (Jakarta: Rajawali Pers, 2011), 1. Lihat juga Satjipto Rahardjo, Ilmu Hukum, vol. III (Bandung: Citra Aditya Bakti, 1991), 352-53.

${ }^{15}$ Soedarto, Hukum dan Hukum Pidana (Bandung: Alumni, 1986), 151. Lihat juga Soedarto, Hukum Pidana dan Perkembangan Masyarakat Kajian terhadap Hukum Pidana (Bandung: Sinar Baru, 1983), 20.

${ }^{16}$ Endrik Safudin, Perubahan Politik Hukum Judicial Review di Indonesia (Studi tentang Peran dan Fungsi Judicial Review dalam Perkembangan Hukum Nasional Kurun Waktu 19452013), Tesis (Program Pasca Sarjana Ilmu Hukum Universitas Sebelas Maret Surakarta, 2012), 18-19. Lihat juga Endrik Safudin, Pengantar Ilmu Hukum (Malang: Setara Press, 2020), 166.

${ }^{17}$ Endrik Safudin, Dasar-Dasar Ilmu Hukum (Malang: Setara Press, 2017), 89.

Kodifikasia: Jurnal Penelitian Islam, Volume, 14 No. 1 Tahun 2020 
publik selaku pengambil keputusan. ${ }^{18}$ Stanley De Smith and Rodney Brazier mengartikan diskresi/freies ermessen sebagai "....power to choose between alternative courses of action.....". ${ }^{19} \mathrm{H}$.W.R. Wade menyebutkan sebuah prinsip utama dari diskresi/freies ermessen adalah "......the rule that the participation of non-members in the deliberation or decision of a collective body may in validate its acts.... ${ }^{20}$ H.F. Abraham Amos lebih memahami diskresi (freies ermessen) sebagai kewajiban dan pejabat pemerintah untuk tidak boleh menolak mengambil keputusan dengan alasan tidak ada peraturannya. ${ }^{21}$

Menurut S.F. Marbun, freies ermessen merupakan kebebasan bertindak atas inisiatif sendiri yang dimungkinkan oleh hukum, untuk menyelesaikan persoalan-persoalan yang penting, mendesak, muncul secara tiba-tiba, yang pengaturannya belum ada atau kewenangannya yang tidak jelas atau samar-samar, yang harus dapat dipertanggungjawabkan baik secara hukum maupun moral. ${ }^{22}$ Menurut Muchsan pembatasan penggunaan freies ermessen yaitu pertama, penggunaan freies ermessen tidak boleh bertentangan dengan sistem hukum yang berlaku (kaidah hukum positif); kedua, penggunaan freies ermessen hanya ditujukan demi kepentingan umum. ${ }^{23}$ Freies ermessen muncul sebagai alternatif untuk mengisi kekurangan dan kelemahan dalam penerapan asas legalitas (wetmatigheid van bestuur). ${ }^{24}$ Ia sebagai pelengkap terhadap asas legalitas, namun bukan mengesampingkan hukumnya sama sekali. $^{25}$

Di Indonesia, kekuasaan diskresi diatur dalam Undang-Undang Nomor 30 Tahun 2014 tentang Administrasi Pemerintahan. Dalam undangundang ini, penggunaan diskresi bertujuan yaitu pertama, melancarkan penyelenggaraan pemerintahan; kedua, mengisi kekosongan hukum; ketiga, memberikan kepastian hukum; keempat, mengatasi stagnasi pemerintahan dalam keadaan tertentu guna kemanfaatan dan kepentingan

${ }^{18}$ Yudhi Setiawan dkk, Hukum Administrasi Pemerintahan: Teori dan Praktik (Dilengkapi dengan Beberapa Kasus Pertanahan), 1 ed., vol. 1 (Depok: Rajawali Pers, 2017), 141-42.

${ }^{19}$ Stanley De Smith dan Rodney Brazier, Constitutional and Administrative Law, 6th ed. (Penguin Books, 1986), 571.

${ }^{20}$ H.W.R. Wade, Administrative Law, 5th ed. (Oxford: English Language Book SocietyOxford University Press, 1982), 132.

${ }^{21}$ Enrico Simanjuntak, "Peradilan Administrasi dan Problematika Peraturan Kebijakan," Majalah Hukum Varia Peradilan XXVI, no. 305 (April 2011): 32.

${ }^{22}$ S.F. Marbun, Peradilan Administrasi Negara dan Upaya Administrasi Di Indonesia, 3 ed. (Yogyakarta: FH UII Press, 2011), 196.

${ }^{23}$ Muchsan, Beberapa Catatan Tentang Hukum Administrasi Negara dan Peradilan Administrasi di Indonesia (Yogyakarta: Liberty, 1981), 27-28.

${ }^{24}$ Ridwan HR, Hukum Administrasi Negara, Revisi 6 (Jakarta: Rajawali Pers, 2011), 170-71.

${ }^{25}$ Amrah Muslimin, Beberapa Asas dan Pengertian Pokok-Pokok Tentang Administrasi Dan Hukum Administrasi (Bandung: Alumni, 1985), 77. 


\section{Endrik Safudin}

umum. ${ }^{26}$ Ruang lingkup diskresi meliputi pertama, peraturan perundangundangan yang memberikan suatu pilihan keputusan dan/atau tindakan; kedua, peraturan perundang-undangan tidak mengatur; ketiga, peraturan perundang-undangan tidak lengkap atau tidak jelas; dan keempat, adanya stagnasi pemerintahan guna kepentingan yang lebih luas. ${ }^{27}$ Sedangkan persyaratan diskresi meliputi pertama, sesuai dengan tujuan diskresi; kedua, tidak bertentangan dengan ketentuan peraturan perundang-undangan; ketiga, sesuai dengan AUPB; keempat, berdasarkan alasan-alasan yang objektif; kelima, tidak menimbulkan konflik kepentingan; dan keenam, dilakukan dengan iktikad baik. ${ }^{28}$

Perlu diketahui bahwa dari freies ermessen akan lahir berbagai peraturan kebijaksanaan (beleidsregel) seperti peraturan kebijaksanaan (beleidsregel) seperti keputusan (beschikking), instruksi (aanschrijving), surat edaran (circulaires), pengumuman (en bekenmaking) dan lain-lainnya bahkan dapat dijumpai dalam bentuk peraturan (regeling).

\section{Konsep Pemisahan dan Pembagian Kekuasaan}

Pemisahan kekuasaan (separation of power) selalu dikaitkan dengan doktrin trias politica yang membagi kekuasaan menjadi tiga macam yaitu legislatif (rule making function), eksekutif (rule aplication function), yudikatif (rule adjudication function). Trias politica menjadi suatu prinsip normatif bahwa kekuasaan-kekuasaan (functions) ini tidak sebaiknya dipasrahkan kepada orang atau badan yang sama sebagai antisipasi penyalahgunaan kekuasaan oleh pihak yang berkuasa. Sehingga diharapkan hak-hak asasi warga negara lebih terjamin. ${ }^{29}$ Munculnya gagasan pembatasan kekuasaan itu dipengaruhi dari pengalaman penumpukan semua cabang kekuasaan negara dalam tangan satu orang atau badan sehingga menimbulkan kekuasaan yang absolut. Misalnya, perkembangan dalam sejarah ketatanegaraan di inggris, raja pernah begitu berkuasa karena menyatukan tiga cabang kekuasaan negara (law-giver, the executor of the law, and the judge) dalam satu tangan. Sebab itu, sejarah pembagian kekuasaan negara berawal dari ide pemisahan

${ }^{26}$ Pasal 22 ayat (2) dan penjelasannya Undang-Undang Nomor 30 Tahun 2014 tentang Administrasi Pemerintahan, Lembaran Negara Republik Indonesia Tahun 2014 Nomor 292, Tambahan Lembaran Negara Republik Indonesia Nomor 5601.

${ }^{27}$ Pasal 23 Undang-Undang Nomor 30 Tahun 2014 tentang Administrasi Pemerintahan.

${ }^{28}$ Pasal 24 Undang-Undang Nomor 30 Tahun 2014 tentang Administrasi Pemerintahan.

${ }^{29}$ Miriam Budiardjo, Dasar-Dasar Ilmu Politik, cet ke-20 (Jakarta: Penerbit PT Gramedia Pustaka Utama, 2005), 151.

Kodifikasia: Jurnal Penelitian Islam, Volume, 14 No. 1 Tahun 2020 
kekuasaan ke dalam berbagai organ supaya tidak terpusat di tangan seorang raja absolut (monarki). ${ }^{30}$

Gagasan pemisahan kekuasaan pertama kali dicetuskan oleh John Locke dalam karyanya "Two Treaties of Civil Government" yang membagi kekuasaan negara menjadi tiga cabang kekuasaan, yaitu legislatif (legislative power), eksekutif (executive power) dan federatif (federative power). Legislatif sebagai kekuasaan yang membentuk undang-undang, eksekutif sebagai kekuasaan yang melaksanakan undang-undang, dan federatif sebagai kekuasaan untuk melakukan hubungan internasional dengan negara lain. ${ }^{31}$ Selanjutnya, konsep John Locke dikembangkan oleh Baron de Montesquiue dengan teori trias politica dalam karyanya L'Espirit des Lois (The Spirit of The Laws) yang membagi menjadi tiga kekuasaan yaitu legislatif, eksekutif dan yudikatif. Teori ini menekankan pemisahan kekuasaan, baik mengenai tugas (fungsi) maupun mengenai alat perlengkapan (lembaga) yang menyelenggarakannya. ${ }^{32}$ Menurut Montesquieu, ketika kekuasaan legislatif dan eksekutif digabungkan pada orang atau badan yang sama, maka hilanglah kebebasan sebab ditemukan bahaya bahwa raja atau badan legislatif yang sama akan melegalkan undang-undang tirani dan mengoperasikannya dengan cara yang tiran pula. ${ }^{33}$

Dalam perkembangannya, setelah abad ke 19 atau dalam negara abad ke-20, trias politica tidak bisa dikukuhkan lagi akibat perkembangan konsep negara kesejahteraan (welfare state). Konsep ini menjadikan pemerintah bertanggungjawab atas kesejahteraan seluruh rakyat, baik menyelenggarakan perencanaan perkembangan ekonomi dan sosial secara menyeluruh. Selain itu, tidak lagi diterima sebagai asas bahwa tiap badan kenegaraan itu hanya bertindak sebagai pelaksana dari undang-undang, tetapi dia berpartisipasi secara aktif di bidang legislatif sendiri (seperti merumuskan rancangan undang-undang, penetapan presiden, peraturan menteri dan sebagainya) dan di bidang yudikatif (seperti penyelesaian sengketa perumahan, konflik pajak). ${ }^{34}$

Dengan keadaan yang demikianlah, ada kecenderungan untuk menafsirkan trias politica tidak lagi sebagai pemisahan kekuasaan (separation of power), tetapi sebagai pembagian kekuasaan (division of power) yang dimaksudkan yaitu hanya fungsi esensiallah yang dibedakan berdasarkan sifatnya serta dipasrahkan kepada badan yang berbeda (distinct hands),

${ }^{30}$ Moh Mahfud M.D, Dasar Dan Struktur Ketatanegaraan Indonesia (Bandung: Rineka Cipta, 2001), 72.

${ }^{31}$ Budiardjo, Dasar-Dasar Ilmu Politik, 183.

${ }^{32} \mathrm{Ibid}, 152$.

${ }^{33}$ CF. Strong, Konstitusi-konstitusi Politik Modern (Bandung: Nusa Media, 2008), 330.

${ }^{34}$ Ibid, 155. 
tetapi untuk selebihnya kerjasama di antara fungsi-fungsi tersebut tetap dibutuhkan untuk kelancaran organisasi. ${ }^{35}$ Perkembangan teori hukum tata negara modern (modern constitutional theory) menunjukkan, cabang-cabang kekuasaan negara semakin berkembang dan desain hubungannya semakin complicated. ${ }^{36}$ Karena itu dalam perkembangannya muncul konsep checks and balances ${ }^{37}$ sebagai akibat peralihan penafsiran pemisahan kekuasaan (separation of power) ke pembagian kekuasaan (division of power) ${ }^{38}$ Checks and balances adalah prinsip saling mengimbangi dan mengawasi antarcabang kekuasaan, biasanya dalam konteks kekuasaan Negara. ${ }^{39}$

Konsep pemisahan kekuasaan dalam negara diatur dalam hukum dasar dari suatu negara yaitu Undang-Undang Dasar atau Konstitusi. Konstitusi atau UUD merupakan dokumen negara yang memuat hal-hal pokok penyelenggaraan negara. ${ }^{40}$ Di Indonesia, konsep pemisahan kekuasaan (separation of power) dan pembagian kekuasaan (division of power atau distribution of power) dikenal dalam perubahan Undang-Undang Dasar 1945. Dalam perubahan Undang-Undang Dasar 1945 terdapat bab III mengenai kekuasaan pemerintahan negara (kekuasaan eksekutif), bab VII mengenai dewan perwakilan rakyat (kekuasaan legislatif), serta bab IX mengenai kekuasaan kehakiman (kekuasaan yudikatif).

Apabila dikaji konsepnya lebih teliti, perkembangan ketatanegaraan Indonesia pasca perubahan Undang-Undang Dasar tahun 1945 secara eksplisit ditentukan lebih dari 3 (tiga) mengenai lembaga negara, malahan dengan penyebutan yang berbeda-beda. Diluar ketentuan Undang-Undang Dasar, ada lembaga-lembaga pembantu (state auxiliary agencies) yang dibentuk berdasarkan undang-undang maupun peraturan lainnya dibawah undang-undang. ${ }^{41}$ Konsep checks and balances dapat dilihat dari berbagai

\footnotetext{
${ }^{35}$ Carl J. Friedrich, Constitutional Government And Democracy: Theory And Practice In Europe And America (Waltham. Mass: Blaisdell Publishing Company, 1967), Bab x.

${ }^{36}$ Baca misalnya Bruce Ackerman, The New Separation Of Powers, vol. 113 (The Harvard Law Review, 2000).

${ }^{37}$ Cheks and balances menurut Peter L. Strauss cenderung dipersamakan dengan distribution of power. Lihat Jimly Asshiddiqie, Pengantar Ilmu Hukum Tata Negara, Jilid i (Jakarta: Sekretariat Jenderal Mahkamah Konstitusi Republik Indonesia, 2006), 296.

${ }^{38}$ Bandingkan dengan Afan Gaffar, Politik Indonesia: Transisi Menuju Demokrasi (Yogyakarta: Pustaka Pelajar, 2006), 89. Sunarto, "Prinsip Checks and Balances Dalam Sistem Ketatanegaraan Indonesia," Jurnal Masalah-Masalah Hukum, Jilid 45, no. 2 (April 2016): 159.

${ }^{39}$ Zulkarnain Ridlwan, "Cita Demokrasi Indonesia dalam Politik Hukum Pengawasan DPR terhadap Pemerintah” Vol. 12, no. 2 (Juni 2015): 312.

${ }^{40}$ Bandingkan dengan Moh. Mahfud MD, Demokrasi dan Konstitusi Indonesia: Studi tentang Interaksi Politik dan Kehidupan Ketatanegaraan. (Jakarta: Rineka Cipta, 2000), 421.

${ }^{41}$ Ni'matul Huda, Undang-Undang Dasar 1945 Dan Gagasan Amandemen Ulang, Cetakan Pertama (Jakarta: Rajawali Grafindo Press, 2008), 277-79. lihat juga Ahmad Yani, "Sistem Pemerintahan Indonesia: Pendekatan Teori Dan Praktek Konstitusi Undang-
}

Kodifikasia: Jurnal Penelitian Islam, Volume, 14 No. 1 Tahun 2020 
kerjasama antar lembaga negara. Misalnya, kerjasama antara presiden (eksekutif) dan Dewan Perwakilan rakyat (legislatif) dalam menjalankan tugas dan fungsinya (ketentuan pasal 4 dan pasal 5 serta dihubungkan pasal 20 Undang-Undang Dasar 1945). Dari sini dapat diketahui bahwa konsep trias politica telah mengalami perubahan, hanya fungsi esensiallah yang dibedakan berdasarkan sifatnya serta dipasrahkan kepada badan yang berbeda yang berbeda (distinct hands), tetapi untuk selebihnya kerjasama di antara fungsi-fungsi tersebut tetap dibutuhkan untuk kelancaran organisasi. Hal ini dikarenakan dalam perkembangannya dalam menjalankan fungsinya kesejahteraan umum (welfare state), hubungan antar cabang kekuasaan tidak mungkin tidak saling bersentuhan, dan bahkan ketiganya (eksekutif, yudikatif dan legislatif) bersifat sederajat dan saling mengendalikan satu sama lain sesuai dengan prinsip cheks and balances. ${ }^{42}$

\section{Politik Hukum Diskresi di Indonesia}

Lahirnya diskresi di Indonesia diawali dari dianutnya asas negara hukum ${ }^{43}$ dan asas negara kesejahteraan (welfare state)..${ }^{44}$ Kedua asas tersebut adalah embrio dari perkembangan politik hukum diskresi yang dibenarkan secara konstitusi. Prinsip negara hukum mendesak disediakannya sarana kekuasaan diskresi bagi pejabat dalam penyelenggaraan pemerintahan untuk mendapatkan legalitasnya. Sebab, setiap perbuatan pemerintah atau pejabat administrasi negara harus berlandaskan peraturan perundangundangan yang sudah ada sebelumnya (wetmatigheid van bestuur), atau sering disebut asas legalitas. Asas legalitas menghendaki perlunya positivisasi hukum dalam penyelenggaraan pemerintahan.

Asas legalitas dikonstruksikan untuk menjamin setiap kebebasan subjek hukum dengan tetap memberikan batasan larangan dan kebolehan secara tepat dan jelas. Asas legalitas juga dikonsepkan untuk melindungi dari kesewenang-wenangan kekuasaan, penyalahgunaan kekuasaan dan anarkisme kekuasaan. Asas legalitas menjadi peringatan sebelum suatu tindakan itu dijalankan mengenai perbuatan-perbuatan yang dilarang dan bagaimana sanksinya. Oleh karena itu, asas legalitas memberikan rumusan

Undang Dasar 1945 (Indonesian Government System: Theory and Practice Approaches of 1945' Constitution)," JIKH Vol. 12, no. 2 (Juli 2018): 119-35.

${ }^{42}$ bandingkan dengan Jimly Asshidiqie, Perkembangan dan Konsilidasi Lembaga Negara Pasca Reformasi (Jakarta: Konstitusi Press, 2006), 31.

${ }^{43}$ Prinsip ini diatur di pasal 1 ayat (3) UUD 1945 (hasil amandemen).

${ }^{44}$ Rumusan dianutnya asas negara kesejahteraan (welfare state) dapat ditemukan di dalam alinea IV pembukaan UUD 1945. 
bahwa tiada ada suatu tindakan yang dilarang selama belum ada suatu ketentuan yang melarangnya. ${ }^{45}$

Apabila prinsip legalitas ini dihubungkan dengan konsep diskresi, maka konsep diskresi memuat makna sebaliknya dari konsep asas legalitas. Konsep diskresi adalah "designed for ordinary and the normal, law cannot always provide for such extraordinary occurrences in spite of its aspiration to comprehensiveness. ${ }^{46}$ Beraksinya asas legalitas, bersifat situasional, yakni tergantung pada situasi yang dihadapi apakah menurut pola yang umum (normal) atau tidak menurut pola yang umum (abnorma) ${ }^{47}$ Menurut Carl Schmitt, adanya sebuah potensi halangan yang besar untuk pemerintah atau pejabat administrasi negara dari keberadaan prinsip legalitas yang gagal dalam memberikan preskripsi secara jelas, presisi, dan lengkap untuk tindakan pemerintah agar dapat terhindar dari situasi demikian. ${ }^{48}$

Oleh karena itu, otorisasi bagi kekuasan diskresi sumbernya bukan asas legalitas, tetapi hukum itu sendiri. Sehingga konsep kekuasaan diskresi merefleksikan muatan moralitas dari hukum. Pernyataan yang bisa dibangun adalah sifat hubungan antara konsep hukum dan undang-undang. Undangundang mempunyai banyak kelemahan seperti kejelasan dan kelengkapan, tetapi hukum tidak. Hukum adalah asas regulatif bagi undang-undang. ${ }^{49}$ Sebagai kekuasan hukum maka diskresi merefleksikan cita hukum yaitu moralitas internal hukum seperti keadilan; sebuah kekuatan yang mampu menyingkirkan keberlakuan undang-undang. ${ }^{50}$

Selain asas negara hukum, asas yang mendasari lahirnya diskresi di Indonesia adalah asas negara kesejahteraan (welfare state). Di anutnya asas tersebut dapat ditemukan di dalam alinea IV pembukaan UUD 1945 yaitu "Kemudian daripada itu untuk membentuk suatu Pemerintah Negara Indonesia yang melindungi segenap bangsa Indonesia dan seluruh tumpah darah Indonesia dan untuk memajukan kesejahteraan umum.....". Dari rumusan tersebut dapat

${ }^{45}$ Dalam catatan sejarah, asas legalitas awal kemunculannya selalu dihubungkan pada teori Von Feurbach (teori Vom Psycologischen Zwang) dengan adagium 'nullum delictum nulla poena sine praevia lege poenali', tiada ada suatu tindak pidana (delik) tiada ada hukuman tanpa didasari suatu peraturan yang mengaturnya terlebih dahulu. Sehingga, dalam teori ini dijelaskan tentang anjuran supaya dalam pengaturan berbagai tindakan yang dilarang, tidak hanya termuat macam-macam tindakannya, tetapi juga jenis pidana yang akan dijatuhkan.

${ }^{46}$ Clement Fatovic, Outside the Law: Executive and Emergency Power (Baltimore: The John Hopkins University Press, 2009), 2.

${ }^{47}$ Krishna Djaya Darumurti, Diskresi: Kajian Teori Hukum (Yogyakarta: GENTA Publishing, 2016), 18.

${ }^{48}$ Kim Lane Scheppele, "Law in a Time of Emergency: States of Exeception and the Temptations of 9/11," University of Pennsylvania Law School, Public Law and Legal Theory Research Papers Series, no. Research Paper No. 60 (2004): 10.

${ }^{49}$ Darumurti, Diskresi: Kajian Teori Hukum, 15.

${ }^{50} \mathrm{Ibid}, 15$. 
diketahui bahwa asas negara kesejahteraan ini juga mendesak negara untuk ikut campur dalam berbagai bidang kehidupan warganya. Oleh karena itu, Asas tersebut merupakan suatu amanat dari Undang-Undang Dasar 1945.

Dalam sejarahnya, dalam konsepsi legal state terkandung asas staatsonthouding atau pembatasan peran negara dalam bidang politik yang berakar pada dalil "the least government is the best government", dan asas "laissez faire, laissez aller" di bidang ekonomi yang menghalangi negara untuk ikut mengurusi kehidupan ekonomi warga negaranya (staatsbemoeienis). Singkatnya, "the state should intervene as little as possible in people's lives and businesses". ${ }^{51}$ Pengekangan ini menjadikan pemerintah menjadi pasif, dan selalu disebut negara penjaga malam (nachtwakerstaat atau nachtwachtersstaat). Sehingga, berdampak pada kesengsaraan warga negara dan pada akhirnya melahirkan reaksi dan kerusuhan sosial. Dengan kata lain, konsep negara penjaga malam tidak berhasil dalam implementasinya. ${ }^{52}$

Kegagalan nachtwachtersstaat melahirkan konsep welfare state yaitu sebuah gagasan untuk menempatkan pemerintah sebagai pihak yang bertanggungjawab atas kesejahteraan rakyatnya. Sehingga, lahirlah kewajiban pemerintah guna mengupayakan kesejahteraan umum untuk warga negaranya. Dengan sebutan lain, ajaran welfare state merupakan wujud konkret dari perpindahan asas staatsonthouding, yang mengontrol peran negara dan pemerintah untuk memasuki kehidupan ekonomi dan sosial masyarakat, menjadi staatsbemoeienis yang mengharapkan negara dan pemerintah ikut aktif di kehidupan ekonomi dan sosial masyarakat, sebagai upaya untuk mengaktualisasikan kesejahteraan umum, disamping merawat ketertiban dan keamanan (rust en orde). ${ }^{53}$ Peralihan prinsip ini sebagai langkah untuk mewujudkan kesejahteraan umum (common walfare).

Penggagas teori welfare state, R. Krenenburg, menyampaikan bahwa negara wajib secara aktif untuk mewujudkan kesejahteraan, bertindak adil yang bisa dinikmati seluruh masyarakat secara merata dan seimbang, tidak hanya memakmurkan golongan tertentu, namun seluruh rakyat. ${ }^{54}$ Sehingga, dalam konsepsi negara kesejahteraan bukan hanya memuat deskripsi tentang sebuah cara pengorganisasian kesejahteraan (welfare) atau pelayanan sosial (social services), tetapi juga sebuah konsepsi normatif

51 AP Le Sueur dan JW Herberg, Constitutional $\mathcal{B}$ Administrative Law (London: Cavendish Publishing Limited, 1995), 53. sebagaimana dikutip Ridwan HR, Hukum Administrasi Negara, 14.

${ }^{52}$ Ridwan HR, Hukum Administrasi Negara, 14.

${ }^{53} \mathrm{Ibid}, 14-15$.

${ }^{54}$ Bernhard Limbong, Pengadaan Tanah untuk Pembangunan: Regulasi, Kompensasi, Penegakan Hukum (Jakarta: Margaretha Pusaka, 2012), 78. 
atau sistem pendekatan ideal yang menegaskan bahwa setiap individu wajib mendapatkan pelayanan sosial yang merupakan haknya. ${ }^{55}$

Dari penjelasan diatas, dalam konteks kekuasaan diskresi, asas negara hukum di rumuskan pasal 1 ayat (3) Undang-Undang Dasar 1945 dan asas negara kesejahteraan (welfare state) dirumusankan dalam alinea IV pembukaan Undang-Undang dasar 1945. Dari kedua asas tersebut selanjutnya dibentuklah Undang-Undang yang mengatur tentang kekuasaan diskresi seperti Undang-Undang Nomor 5 Tahun 1974 Tentang Pokok-Pokok Pemerintahan Daerah, Undang-Undang-Undang Nomor 5 Tahun 1986 Tentang Peradilan Tata Usaha Negara, dan Undang-Undang Nomor 30 Tahun 2014 tentang Administrasi Pemerintahan.

Perlu dicatat juga bahwa sebuah pertimbangan tentang embrio munculnya kekuasaan diskresi dalam sistem hukum di Indonesia adalah rumusan pasal 22 ayat (1) UUD 1945 yaitu: "dalam hal ihwal kegentingan yang memaksa, Presiden berhak menetapkan peraturan pemerintah sebagai pengganti undang-undang." Dalam kepustakaan Hukum Administrasi Negara, ketentuan pasal 22 sebagai noodverondeningrecht Presiden yang mengandung pengertian hak Presiden untuk membuat peraturan darurat (noodverondening). ${ }^{56} \mathrm{Hal}$ ini dikarenakan Presiden sebagai kepala eksekutif yang menjalankan hukum administrasi negara.

Dengan demikian, dapat diketahui bahwa kekuasaan diskresi lahir dari prinsip negara hukum dan prinsip negara kesejahteraan (welfare state). Kedua prinsip tersebut memaksa untuk diberikannya kekuasaan diskresi kepada pemerintah. Hal ini ada 2 (dua) faktor yang menjadi sebab yaitu pertama, adanya realitas yang sering dihadapi. Kebutuhan untuk menciptakan peraturan perundang-undangan sebagai landasan bertindak pemerintah, tidak pernah dan tidak pernah mampu mengatur semua urusan dalam usaha mensejahterakan warga sampai ke suatu permasalahan yang konkrit, individual dalam dinamika masyarakat yang selalu berubah. Kedua, adanya kewajiban pemerintah untuk mewujudkan negara kesejahteraan. Pelaksanaan cita kesejahteraan ini mewajibkan pemerintah untuk ikut campur dalam setiap bidang kehidupan masyarakat.

Perlu diketahui bahwa kekuasaan diskresi diletakkan dalam koridor negara hukum karena kekuasaan ini mengandung tujuan tertentu. Tujuan

${ }^{55} \mathrm{Ibid}, 75$.

${ }^{56}$ Pengertian pasal 22 UUD 1945 selalu disandingkan dengan pasal 12 UUD 1945 yaitu "Presiden menyatakan keadaan bahaya. Syarat-syarat dan akibatnya keadaan bahaya ditetapkan dengan undang-undang." Di pasal 12 UUD 1945 mengandung makna staatnoodrecht. Staat diartikan sebagai keadaan bukan negara, sedangkan recht diartikan hukum, sehingga noodrecht diartikan hukum darurat. Sehingga staatnoodrecht artinya hukum (dalam keadaan) darurat. Bagir Manan, DPR, DPD dan MPR dalam UUD 1945 Baru (Yogyakarta: FH-UII Press, 2003), 42-43.

Kodifikasia: Jurnal Penelitian Islam, Volume, 14 No. 1 Tahun 2020 
tersebut berfungsi mengontrol, membatasi dan mengawasi tindakan diskresi, yang secara absah membolehkan pemerintah bertindak menyimpang dari asas legalitas. Sedangkan diletakkan dalam koridor negara kesejahteraan, kekuasaan diskresi adalah kekuasaan yang mengandung tujuan umum. Tujuan tersebut berfungsi untuk mengarahkan atau sebagai cita umum dalam melaksanakan kekuasaan diskresi, yang secara absah membolehkan pemerintah bertindak untuk ikut campur dalam kehidupan warganya.

\section{Diskresi sebagai Bentuk Pembagian Kekuasaan}

Pemikiran diskresi sebagai bentuk pembagian kekuasaan antara pemerintah (eksekutif) dan pembentuk undang-undang (legislatif) di awali dari pemikiran filsuf inggris, John Locke tentang pemisahan kekuasaan. Oleh karena itu, pendapat Locke akan dipakai untuk memahami hakikat diskresi sebagai bentuk pembagian kekuasaan.

Di dalam two treatises on civil goverment (1690), John Locke mengkritik kekuasaan mutlak raja-raja Stuart serta sebagai pembenaran revolusi gemerlap pada tahun 1688 (glorious revolution of 1688). John Locke memisahkan tiga macam kekuasaan negara yaitu: legislative, executive, dan federative. ${ }^{57}$ Konsep pemisahan kekuasaan tersebut memberikan inspirasi kepada Montesquieu. ${ }^{58}$ Dalam bukunya esprit des lois (1948), Montesquieu dengan teori trias politica-nya membagi menjadi 3 (tiga) kekuasaan yaitu legislatif, eksekutif, dan yudikatif. Pembagian kekuasaan di Amerika Serikat adalah gambaran pelaksanaan ide trias politica Montesquieu. Ketiga kekuasaan tersebut harus dipisahkan secara mutlak sehingga muncul adanya check and balance. Pemisahan kekuasaan dengan asas 'check and balance' seperti di Amerika Serikat bisa mengurangi timbulnya tirani dan diktator. ${ }^{59}$

Montesquieu mengharapkan pemisahan kekuasaan secara tegas pada ketiga cabang kekuasaan tersebut, baik berkaitan dengan fungsi maupun alat kelengkapannya (organ) yang melaksanakan kekuasaan tersebut. Pemisahan kekuasaan sebagai prasyarat independensi yudikatif, karena akan melindungi kemerdekaan individu dan hak asasi manusia. Asas persamaan di depan hukum sebagai suatu elemen yang substansial dalam konsep the rule of law. Pemisahan kekuasaan dipandang sebagai sesuatu yang absolut oleh Montesqueiu.

\footnotetext{
${ }^{57}$ Budiardjo, Dasar-Dasar Ilmu Politik, 151-52.

${ }^{58}$ Benny K. Harman, Konfigurasi Politik dan Kekuasaan Kehakiman di Indonesia (Jakarta: Elsam, 1997), 48-49.

${ }^{59}$ Lihat CC. Rodde et.al, Pengantar Ilmu Politik (Introduction to Political Science), cet. IV, diterjemahkan oleh Zulkifli Hamid (Jakarta: RajaGrafindo Persada, 2000), 66-67. Lihat juga Suparto, "Pemisahan Kekuasaan, Konstitusi dan Kekuasaan Kehakiman Yang Independen Menurut Islam," JURNAL SELAT Volume. 4, no. 1 (Oktober 2016): 117-18.
} 
Oleh karena itu, kemerdekaan sejati dapat dijamin, jika ketiga kekuasaan negara tidak dikendalikan pada satu tangan atau organ, namun pada badan (organ) yang masing-masing terpisah, dan memiliki keseimbangan serta masing-masing dapat saling mengontrol. Jika kekuasaan legislatif dan eksekutif serta yudikatif dikendalikan pada satu tangan atau satu badan (organ) kekuasaan, maka hilanglah independensi, dan melahirkan musibah bagi negara yang bersangkutan dan bagi kemerdekaan (liberty) individu. ${ }^{60}$

Pemisahan kekuasaan dan 'checks and balances' dikonstruksikan sebagai prinsip-prinsip yang bisa mencegah pemusatan kekuasaan di bawah satu tangan atau organ dan melarang adanya intervensi antara badan/organ negara, sehingga masing-masing bisa melaksanakan tugas dan fungsinya seperti yang ditentukan dalam konstitusi negara yang bersangkutan. Untuk mengontrol jangan sampai suatu kekuasaan legislatif yang dilaksanakan oleh parlemen memiliki kekuasaan yang melampaui badan (organ) lainnya, bisa diformulasikan kerjasama antarlembaga kekuasaan negara, misalnya kerjasama parlemen dengan pemerintah (presiden) di dalam pembuatan suatu undang-undang.

Demikian pula untuk mengontrol agar kekuasaan eksekutif tidak melampaui kekuasaan badan (organ) lainnya, misalnya dengan memberikan kewenangan lembaga legislatif disamping sebagai pembuat undang-undang, juga melaksanakan pengawasan terhadap pemerintah, pemberi persetujuan, serta pemberi pertimbangan untuk beberapa keputusan yang diambil oleh pemerintah, misalnya pengangkatan pejabat negara tertentu. ${ }^{61}$

Disamping asas pemisahan kekuasaan, juga terdapat asas pembagian kekuasaan yang menurut Ismail Sunny dengan mendasarkan pada pemikiran Jennings yang membedakan pemisahan kekuasaan negara dalam arti materiil dan pemisahan kekuasaan dalam arti formal. Pemisahan kekuasaan dalam arti materiil adalah pemisahan kekuasaan dalam arti pembagian kekuasaan itu dikukuhkan dengan tegas dalam tugas-tugas kenegaraan yang mempertunjukkan adanya pemisahan kekuasaan, yaitu legislatif, eksekutif dan yudikatif. Sedangkan pemisahan kekuasaan dalam arti formal adalah pembagian kekuasaan tidak dilaksanakan secara tegas. Pemisahan kekuasaan dalam arti materiil disebut "separation of power", dalam arti formal disebut "division of power". ${ }^{62}$

${ }^{60}$ Charles De Scondat, Baron de Montesqueiu, The Spirit of Laws, revised by J.V. Prichard, translated by Thomas Nugent (London: G. Bell \& Son, 1914), 153.

${ }^{61}$ Lihat pasal 20 ayat (1) dan (2), pasal 13 ayat (2) dan (3), pasal 14 ayat (2), pasal 20A ayat (1) UUD Negara RI 1945 jo. Pasal 33 ayat (2) huruf c UU No. 4 Thn 1999 tentang susduk MPR, DPR dan DPRD, jo. Pasal 26 ayat (1) huruf f, j, k, 1, m dan n UU No. 22 Thn 2003 tentang Susduk MPR, DPR, DPD dan DPRD.

${ }^{62}$ Ismail Sunny, Pembagian Kekuasaan Negara (Jakarta: Aksara Baru, 1982), 3. 
Asas pembagian kekuasaan negara bukan dimaksudkan kekuasaan di bagi tanpa sisa kepada lembaga-lembaga. Tetapi, kekuasaan itu dibagi pada lembaga yang oleh konstitusi diberikan kewenangan untuk membagi kekuasaan negara, seperti MPR sebagai lembaga tertinggi dalam UUD 1945 (sebelum amandemen) membagi kekuasaan negara kepada lembaga-lembaga negara dibawahnya. Asas pembagian kekuasaan lebih mendahulukan adanya kekuasaan tertinggi yang mengatur dan memperoleh pertanggungjawaban atas pelaksanaan kekuasaan yang diberikan. Hal ini sering disebut "supremasi parlemen" (supremacy of parliament), parlemen lebih berkuasa dalam memastikan arah dalam penyelenggaraan negara.

Di Indonesia, asas kekuasaan negara menurut perspektif UUD 1945 (sebelum amandemen) tidak meyakini asas pemisahan kekuasaan dalam arti materiil (separation of power), tetapi mempraktikkan asas pemisahan kekuasaan dalam arti formal (division of power). ${ }^{63}$ UUD 1945 (sebelum amandemen) memastikan bahwa kedaulatan berada ditangan rakyat dan dijalankan seutuhnya oleh MPR. Artinya, sumber kekuasaan itu hanya ada di rakyat dan MPR yang memiliki kekuasaan tertinggi untuk dan atas nama rakyat. Sumber kekuasaan diberikan pada MPR dan berfungsi terus dan tidak habis, walaupun sebagian kekuasaan diberikan kepada lembaga negara lain. Artinya, konteks hubungan MPR dengan lembaga negara dibawahnya adalah asas "delegasi kekuasaan" (delegation of power). Pada asas delegasi kekuasaan, MPR sebagai lembaga tertinggi negara mendistribusikan kekuasaannya kepada lembaga-lembaga negara yang telah ditetapkan dalam UUD 1945. Sehingga, lahirlah pertanggungjawaban kekuasaan dari penerima delegasi kepada pemberi delegasi, yaitu lembaga-lembaga tinggi negara kepada lembaga tertinggi negara.

Prinsip pembagian kekuasaan di Indonesia dianut UUD 1945 selama kurun waktu 1970-1998. Akibatnya sangat berpengaruh terhadap sistem kekuasaan di Indonesia sebagaimana tercermin dari berbagai produk hukum. Dalam konteks kekuasaan kehakiman, Mahkamah Agung dan peradilan yang ada dibawahnya hanya dijadikan corong undang-undang dan bukan corong hukum dan keadilan. Sehingga kekuasaan kehakiman yang bebas dan merdeka sebagaimana yang diatur dalam pasal 24 UUD 1945, tidak sepenuhnya dapat diwujudkan.

Sedangkan dalam asas 'pemisahan kekuasaan' dan 'checks and balances', pengawasan dapat dilakukan terhadap semua lembaga negara. Hal ini dikarenakan tidak ada superioritas dalam satu organ negara, tetapi justru seluruh lembaga negara kedudukannya sederajat dan dibedakan pada fungsi dan tugas masing-masing. Asas 'checks and balances' sudah nampak dalam

\footnotetext{
${ }^{63}$ Ibid, 3.
} 
UUD 1945 (hasil amandemen). Konsep ketatanegaraan setelah amandemen sudah memposisikan semua lembaga mempunyai kedudukan sejajar sehingga adanya kerjasama dan 'checks and balances' dalam menjalanakan fungsi ketatanegaraan.

Dari pembahasan diatas, pemikiran tentang diskresi sebagai bentuk pembagian kekuasaan antara pemerintah (eksekutif) dan pembentuk undang-undang (legislatif) sudah mendapatkan asumsi dasar rasionalitasnya. Pemisahan kekuasaan yang di awali dari pemikiran Locke dan dikembangkan oleh Montesquieu bertujuan untuk kemaslahatan umat (public good) sehingga proses ketatanegaraan tidak jatuh pada otoritarisme. Atas justifikasi tentang kemaslahatan umat (public good) melahirkan sebuah konsep diskresi yang merupakan hak prerogatif (prerogative) pemerintah.

Pada hakikatnya, diskresi yang dijalankan oleh pemerintah adalah bentuk pembagian kekuasaan yang diberikan oleh lembaga legislatif. Pemerintah memperoleh "inderect legislative powers to make exceptions to duly enacted laws of the commonwealth when strict adherence to them would undermine the public good". ${ }^{64}$ Konsep ini selaras dengan asas non-delegasi atau delegatus non potest delegare karena Locke telah memastikan bahwa "legislative cannot transfer the power of making laws to any other hand.". ${ }^{65}$ Dalam konteks ini pertimbangan kemaslahatan umat (public good) menjadi alasan dijalankannya kekuasaan diskresi. Diskresi sebagai sebuah bentuk pembagian kekuasaan antara legislatif dan eksekutif dimaksudkan untuk memperlancar perwujudan negara kesejahteraan (welfare state). Sehingga, pemerintah dalam mengambil tindakan diskresi harus mempertimbangkan terlebih dahulu ada tidaknya tuntutan kemaslahatan umat (public good).

Tujuan negara, dalam kerangka pikir Locke, merupakan isu utama. Pemahaman mengenai tujuan negara akan memberikan pemahaman mengenai hakikat pemerintahan. Locke meletakkan tujuan negara pada pertimbangan mengapa manusia memutuskan mendirikan sebuah negara, yaitu dalam rangka "the mutual preservation of their lives, liberties and estates" ${ }^{6}{ }^{6}$ Untuk mendukung asas negara hukum, maka kaidah fundemantal bagi negara adalah "establishing of the legislative power" ${ }^{67}$ Locke mendudukan kekuasaan legislatif dan eksekutif terpisah secara fungsional dalam rangka menegakkan asas nemo iudex in causa sua (seseorang tidak boleh menjadi hakim untuk dirinya sendiri). ${ }^{68}$ Dalam hubungannya dengan kekuasaan

\footnotetext{
${ }^{64}$ Fatovic, Outside the Law: Executive and Emergency Power, 53.

${ }^{65} \mathrm{Ibid}, 53$.

${ }^{66} \mathrm{Ibid}, 53$.

${ }^{67} \mathrm{Ibid}, 53$.

${ }^{68} \mathrm{Ibid}, 53$.
} 
legislatif, kekuasaan eksekutif (pemerintah) Locke memiliki kekuasaan prerogratif (diskresi). ${ }^{69}$

Secara teoritis, prinsip dalam penentuan tujuan dari kekuasaan pemerintah adalah undang-undang yang dibuat lembaga legislatif. Begitu juga, prinsip legalitas dari kekuasaan diskresi adalah hukum dan/atau undang-undang. Pertimbangan legislative intent dari undang-undang yang posisinya adalah memberikan kekuasaan atributif terhadap pemerintah sebagai dasar tindaknya. Legislative intent pada hakikatnya yang akan menggariskan tujuan dari kekuasaan yang diatribusikan kepada pemerintah oleh badan legislatif secara tersurat atau tersirat. ${ }^{70}$ Secara teoritis pula bahwa konstitusi merupakan sumber hukum yang menjadi landasan yuridis untuk perolehan kekuasaan atau kewenangan pemerintah, baik dengan konstitusi memberikan kekuasaan atributif secara langsung atau secara tidak langsung, yaitu memberikan kekuasaan atributif kepada pembentuk undang-undang untuk memberikan kekuasaan atributif yang dibutuhkan, termasuk memberikan delegatif, kepada pemerintah supaya memiliki kapasitas yuridis dalam melakukan tindak-tindak pemerintahan. ${ }^{71}$ Oleh karena itu, dapat disimpulkan bahwa ada tiga cara untuk memperoleh kekuasaan secara yuridis yaitu atribusi (attribution), delegasi (delegation) dan mandat (mandate). ${ }^{72}$

Dengan demikian, dapat diketahui bahwa diskresi sebagai bentuk pembagian kekuasaan antara legislatif dan eksekutif mendapatkan rasionalitas dalam negara modern ini. Rasionalitas ini khususnya ketika pemerintah dihadapkan pada suatu peristiwa konkret yang mendesak untuk segera di ambil sebuah keputusan atau tindakan sedangkan peraturan perundang-undangan tidak mengatur, memberi pilihan atau ada kekosongan peraturan perundang-undangan.

Sehingga, konsep diskresi sebagai sebuah bentuk pembagian kekuasaan antara eksekutif dan legislatif mendapatkan legalitas. Sebagian kekuasaan yang dipegang oleh badan pembentuk undang undang (legislatif) dipindahkan atau dibagikan ke dalam tangan pemerintah/ administrasi negara (eksekutif). Artinya, konsep pembagian disini sebagai

${ }^{69}$ Darumurti, Diskresi: Kajian Teori Hukum, 107.

${ }^{70} \mathrm{Ibid}, 126$.

${ }^{71}$ Ibid, 153.

72 Atribusi mengarah pada kewenangan yang orisinil atas dasar konstitusi (UUD dan UU). Delegasi mengarah pada suatu pelimpahan wewenang kepada organ pemerintahan yang lain. Mandat tidak ada pelimpahan apapun dalam arti pemberian wewenang, akan tetapi, penerima mandat bertindak atas nama pemberi mandat. Pejabat yang memberi mandat menunjuk pejabat lain untuk bertindak atas nama mandator (pemberi mandat). Lihat Yuniar Kurniawaty Kurniawaty, "Penggunaan Diskresi Dalam Pembentukan Produk Hukum (The Use of Discretion in The Formation of a Legal Product)," 59. 
maksud untuk memunculkan konsep kerjasama antar lembaga negara khususnya kerjasama antara legislatif dan eksekutif. Lembaga eksekutif tidak hanya melaksanakan peraturan peraturan perundang-undangan, tetapi juga membuat peraturan kebijaksanaan yang didasarkan pada freies ermessen seperti keputusan, instruksi, surat edaran, pengumuman dan lainlainnya bahkan dapat dijumpai dalam bentuk peraturan. Perlu menjadi catatan bahwa, sisi positif dari bentuk pembagian kekuasaan antara eksekutif dan legislatif adalah terjalinnya keterikatan pemerintah terhadap undang-undang lebih dinaminis-fleksibel-situasional ketika menghadapi situasi-situasi yang kasuistis atau persoalan konkret yang membutuhkan penyelesaian. Meskipun demikian, pelaksanaan diskresi yang dilakukan pemerintah harus dibatasi dan mendapatkan batasan oleh hukum. Disinilah, keterikatan hubungan pemerintah dan hukum menjadi absolut.

\section{PENUTUP}

\section{Kesimpulan}

Berdasarkan pembahasan di atas dapat ditarik kesimpulan bahwa diskresi di Indonesia merupakan amanah konstiusi yaitu UUD 1945. Politik hukum disekresi dimaksudkan untuk mempercepat tugas pemerintah dalam mewujudkan negara kesejahteraan (welfare state). Artinya diskresi sebagai sarana responsif untuk menjawab kebutuhan rakyat yang dimiliki oleh pemerintah. Sehingga, pemerintah mempunyai kekuasaan atas inisiatifnya sendiri ketika dihadapkan pada persoalan konkret yang mendesak untuk diambil sebuah keputusan atau tindakan. Meskipun demikian, pelaksanaan kekuasaan diskresi ini tetap mendapatkan batasan dari hukum.

Politik hukum diskresi juga sebagai bentuk pembagian kekuasaan antara pemerintah dan legislatif telah mendapatkan rasionalitas keabsahannya. Rasionalitas ini didasarkan pada pertimbangan legislative intent dari pembuat undang-undang (legislatif). Pertimbangan ini berasal dari undang-undang yang posisinya adalah memberikan kekuasaan atributif terhadap pemerintah sebagai dasar tindaknya. Selain itu, sebagai wujud kesadaran dari lembaga legislatif bahwa produk undang-undang yang telah dibuat tidak selamanya memberikan sebuah penyelesaian ketika pemerintah dihadapkan pada peristiwa konkret yang mendesak membutuhkan keputusan atau tindakan. Sehingga, alasan ini menjadi salah satu diberikannya kekuasaan diskresi kepada pemerintah (eksekutif). 


\section{DAFTAR RUJUKAN}

Ackerman, Bruce. The New Separation Of Powers. Vol. 113. The Harvard Law Review, 2000.

Apeldroon, L.j. Van. Pengantar Ilmu Hukum. Bandung: PT. Pradnya Paramita, 2001.

Asshiddiqie, Jimly. Pengantar Ilmu Hukum Tata Negara. Jilid i. Jakarta: Sekretariat Jenderal Mahkamah Konstitusi Republik Indonesia, 2006.

Asshidiqie, Jimly. Perkembangan dan Konsilidasi Lembaga Negara Pasca Reformasi. Jakarta: Konstitusi Press, 2006.

Budiardjo, Miriam. Dasar-Dasar Ilmu Politik. cet ke-20. Jakarta: Penerbit PT Gramedia Pustaka Utama, 2005.

Darumurti, Krishna Djaya. Diskresi: Kajian Teori Hukum. Yogyakarta: GENTA Publishing, 2016.

Enrico Simanjuntak. "Peradilan Administrasi dan Problematika Peraturan Kebijakan.” Majalah Hukum Varia Peradilan XXVI, no. 305 (April 2011).

Fatovic, Clement. Outside the Law: Executive and Emergency Power. Baltimore: The John Hopkins University Press, 2009.

Friedrich, Carl J. Constitutional Government And Democracy: Theory And Practice In Europe And America. Waltham. Mass: Blaisdell Publishing Company, 1967.

Gaffar, Afan. Politik Indonesia: Transisi Menuju Demokrasi. Yogyakarta: Pustaka Pelajar, 2006.

Gillisen, Emeritus John, dan Emeritus Frits Gorle. Sejarah Hukum: Suatu Pengantar. Bandung: PT. Refika Aditama, 2005.

Hadi, Sofyan. "Fungsi Legislasi dalam Sistem Pemerintahan Presidensil (Studi Perbandingan Indonesia dan Amerika Serikat).” Jurnal Ilmu Hukum DIH vol 9, no. 18 (Februari 2013).

Harman, Benny K. Konfigurasi Politik dan Kekuasaan Kehakiman di Indonesia. Jakarta: Elsam, 1997.

HR, Ridwan. Hukum Administrasi Negara. Revisi 6. Jakarta: Rajawali Pers, 2011. 
Huda, Ni'matul. Undang-Undang Dasar 1945 Dan Gagasan Amandemen Ulang. Cetakan Pertama. Jakarta: Rajawali Grafindo Press, 2008.

Kelsen, Hans. General Theory of Law and State. Cambridge, Massachusetts: Harvard University Press, 1949.

Kurniawaty, Yuniar. "Penggunaan Diskresi Dalam Pembentukan Produk Hukum (The Use of Discretion in The Formation of a Legal Product)." Jurnal Legislasi Indonesia Vol. 13, no. 01 (Maret 2016).

Limbong, Bernhard. Pengadaan Tanah untuk Pembangunan: Regulasi, Kompensasi, Penegakan Hukum. Jakarta: Margaretha Pusaka, 2012.

Mahfud M.D, Moh. Dasar Dan Struktur Ketatanegaraan Indonesia. Bandung: Rineka Cipta, 2001.

Mahfud MD, Moh. Demokrasi dan Konstitusi Indonesia: Studi tentang Interaksi Politik dan Kehidupan Ketatanegaraan. Jakarta: Rineka Cipta, 2000.

Politik Hukum di Indonesia. Revisi. Vol. Keempat. Jakarta: Rajawali Pers, 2011.

Manan, Bagir. DPR, DPD dan MPR dalam UUD 1945 Baru. Yogyakarta: FH-UII Press, 2003.

Marbun, S.F. Peradilan Administrasi Negara dan Upaya Administrasi Di Indonesia. 3 ed. Yogyakarta: FH UII Press, 2011.

Muchsan. Beberapa Catatan Tentang Hukum Administrasi Negara dan Peradilan Administrasi di Indonesia. Yogyakarta: Liberty, 1981.

Muhlizi, Arfan Faiz. "Reformasi Diskresi Dalam Penataan Hukum Administrasi (Reformation of Descretion In The Arrangement Administrative Law)." Jurnal Rechts Vinding Volume 1, no. 1 (April 2012).

Muslimin, Amrah. Beberapa Asas dan Pengertian Pokok-Pokok Tentang Administrasi Dan Hukum Administrasi. Bandung: Alumni, 1985.

Rahardjo, Satjipto. Ilmu Hukum. Vol. III. Bandung: Citra Aditya Bakti, 1991.

Ridlwan, Zulkarnain. "Cita Demokrasi Indonesia dalam Politik Hukum Pengawasan DPR terhadap Pemerintah” Vol. 12, no. 2 (Juni 2015).

Rodde, CC., et.al. Pengantar Ilmu Politik (Introduction to Political Science). Cet. IV. diterjemahkan oleh Zulkifli Hamid. Jakarta: RajaGrafindo Persada, 2000. 
Safudin, Endrik. Dasar-Dasar Ilmu Hukum. Malang: Setara Press, 2017.

_. Pengantar Ilmu Hukum. Malang: Setara Press, 2020.

. Perubahan Politik Hukum Judicial Review di Indonesia (Studi tentang Peran dan Fungsi Judicial Review dalam Perkembangan Hukum Nasional Kurun Waktu 1945-2013). Tesis. Program Pasca Sarjana Ilmu Hukum Universitas Sebelas Maret Surakarta, 2012.

"Politik Hukum HAM di Indonesia." Justitia Islamica 12, no. 1 (2015).

Scheppele, Kim Lane. "Law in a Time of Emergency: States of Exeception and the Temptations of 9/11." University of Pennsylvania Law School, Public Law and Legal Theory Research Papers Series, no. Research Paper No. 60 (2004).

Scondat, Charles De. Baron de Montesqueiu, The Spirit of Laws. Revised by J.V. Prichard. translated by Thomas Nugent. London: G. Bell \& Son, 1914.

Setiawan, Yudhi, dkk. Hukum Administrasi Pemerintahan: Teori dan Praktik (Dilengkapi dengan Beberapa Kasus Pertanahan). 1 ed. Vol. 1. Depok: Rajawali Pers, 2017.

Sihotang, Githa Angela, Pujiyono, dan Nabitatus Sa'adah. "Diskresi dan Tanggungjawab pejabat publik pada pelaksanaan tugas dalam situasi darurat." Jurnal Law Reform 13, no. 1 (Tahun 2017).

Smith, Stanley De, dan Rodney Brazier. Constitutional and Administrative Law. 6th ed. Penguin Books, 1986.

Soedarto. Hukum dan Hukum Pidana. Bandung: Alumni, 1986.

Hukum Pidana dan Perkembangan Masyarakat Kajian terhadap Hukum Pidana. Bandung: Sinar Baru, 1983.

Soekanto, Soerjono. Pengantar Sejarah Hukum. Bandung: Alumni, 1986.

Stefanus, Kotan Y. Perkembangan Kekuasaan Pemerintahan Negara. Yogyakarta: Penerbit Universitas Atma Jaya, 1998.

Strong, CF. Konstitusi-konstitusi Politik Modern. Bandung: Nusa Media, 2008.

Sueur, AP Le, dan JW Herberg. Constitutional $\mathcal{E}$ Administrative Law. London: Cavendish Publishing Limited, 1995. 
Sunarto. "Prinsip Checks and Balances Dalam Sistem Ketatanegaraan Indonesia,." Jurnal Masalah-Masalah Hukum, Jilid 45, no. 2 (April 2016).

Sunny, Ismail. Pembagian Kekuasaan Negara. Jakarta: Aksara Baru, 1982.

Suparto. "Pemisahan Kekuasaan, Konstitusi dan Kekuasaan Kehakiman Yang Independen Menurut Islam.” JURNAL SELAT Volume. 4, no. 1 (Oktober 2016).

Tanya, Bernard L. Politik Hukum Agenda Kepentingan Bersama. Yogyakarta: Genta Publishing, 2011.

Undang-Undang Nomor 30 Tahun 2014 tentang Administrasi Pemerintahan, Lembaran Negara Republik Indonesia Tahun 2014 Nomor 292, Tambahan Lembaran Negara Republik Indonesia Nomor 5601 (t.t.).

Utrecht, E. Pengantar Hukum Administrasi Negara Indonesia. Surabaya: Pustaka Tinta Mas, 1988.

Wade, H.W.R. Administrative Law. 5th ed. Oxford: English Language Book Society-Oxford University Press, 1982.

Yani, Ahmad. "Sistem Pemerintahan Indonesia: Pendekatan Teori Dan Praktek Konstitusi Undang-Undang Dasar 1945 (Indonesian Government System: Theory and Practice Approaches of 1945' Constitution),." JIKH Vol. 12, no. 2 (Juli 2018).

Yuhdi, Mohammad. "PERANAN DISKRESI DALAM PENYELENGGARAAN PEMERINTAHAN.” Jurnal Ilmiah.Fakultas Keguruan dan Ilmu Pendidikan Volume. 15, no. 1 (t.t.).

Yulistyowati, Efi, Endah Pujiastuti, dan Tri Mulyani. "Penerapan Konsep Trias Politica Dalam Sistem Pemerintahan Republik Indonesia: Studi Komparatif Atas Undang-Undang Dasar Tahun 1945 Sebelum Dan Sesudah Amandemen." Jumal Dinamika Sosial Budaya Volume 18, no. 2 (Desember 2016). 